\title{
Exploring beyond palladium: Catalytic reduction of aqueous oxyanion pollutants with alternative platinum group metals and new mechanistic implications
}

\author{
Xi Chen, ${ }^{\dagger, \# ~ X i a n g c h e n ~ H u o, ~}{ }^{\ddagger, \#}$ Jinyong Liu, ${ }^{,, \S, \#}$ Yin Wang, ${ }^{\prime}$ Charles J. Werth, ${ }^{\Delta}$ \\ and Timothy J. Strathmann
}

\footnotetext{
'Department of Earth and Environmental Engineering, Columbia University, New York, NY 10027, United States

${ }^{\star}$ Department of Civil and Environmental Engineering, Colorado School of Mines, Golden, CO 80401, United States

${ }^{\S}$ Department of Chemical and Environmental Engineering, University of California, Riverside, CA 92521, United States

'Department of Civil and Environmental Engineering, University of Wisconsin-Milwaukee, Milwaukee, WI 53211, United States

${ }^{\Delta}$ Department of Civil, Architectural, and Environmental Engineering, University of Texas at Austin, Austin, TX 78712, United States
}

\section{AUTHOR INFORMATION \\ "These authors contributed equally. \\ *Corresponding Author}

Phone: +1(217) 552-5670. Email: jinyong.liu101@gmail.com; jyliu@engr.ucr.edu. 


\begin{abstract}
For over two decades, $\mathrm{Pd}$ has been the primary hydrogenation metal studied for reductive catalytic water treatment applications. Herein, we report that alternative platinum group metals ( Rh, Ru, Pt and Ir) can exhibit substantially higher activity, wider substrate selectivity and variable $\mathrm{pH}$ dependence in comparison to Pd. Cross comparison of multiple metals and oxyanion substrates provides new mechanistic insights into the heterogeneous reactions. Activity differences and $\mathrm{pH}$ effects mainly originate from the chemical nature of individual metals. Considering the advantages in performance and cost, results support renewed investigation of alternative hydrogenation metals to advance catalytic technologies for water purification and other environmental applications.
\end{abstract}

Keywords: rhodium, ruthenium, bromate, chlorate, water treatment, reductive catalysis

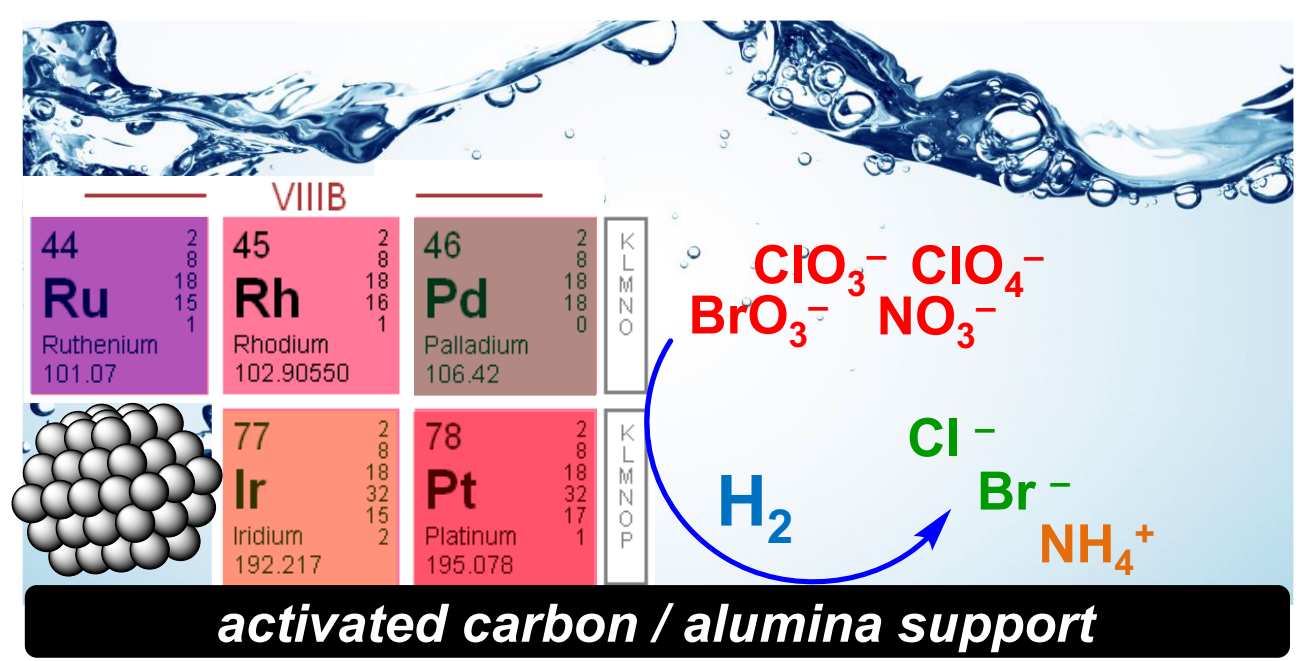




\section{INTRODUCTION}

Toxic oxyanions, such as $\mathrm{BrO}_{3}{ }^{-}, \mathrm{ClO}_{3}{ }^{-}, \mathrm{NO}_{3}{ }^{-}$and $\mathrm{ClO}_{4}^{-}$, are ubiquitous drinking water contaminants originating from both anthropogenic and natural sources [1-4], or are generated during water treatment processes (e.g., chlorination, ozonation, desalination, and electrochemical treatment) [5-9]. These ions target multiple organs, and can have carcinogenic, mutagenic, and/or endocrine disrupting properties [10-12]. Ion exchange is the primary technology used to treat oxyanion-contaminated water; reverse osmosis is also used when salt removal is required. These technologies effectively serve to either trap the contaminants in a resin matrix, or to concentrate the contaminants in a waste brine. Thus, it would be preferable to apply destructive treatment technologies to convert oxyanions into less toxic or innocuous end products (e.g., $\mathrm{Br}^{-}, \mathrm{Cl}^{-}$and $\mathrm{N}_{2}$ ), contributing to more sustainable drinking water treatment processes [13-16].

Pd-based heterogeneous catalysis has garnered significant attention as a potential strategy for reduction of oxyanions and other highly oxidized contaminants (e.g., halogenated and nitro organics) [17]. Ever since 1993 when Pd was identified as the "optimum" hydrogenation metal for water treatment applications (based on the screening of hydrogenation metals for nitrite reduction [18]), research efforts have reported on many aspects of Pd-based catalysis, including the effects of Pd nanoparticle size and morphology [19], catalyst supports [20-23], bimetallic formulations for treating recalcitrant substrates [14, 24, 25], water matrix effects [26, 27], and pilot-scale field testing [28-30]. We argue here that the narrow focus on Pd has limited advancement of reductive water treatment catalyst technologies. Little effort has been devoted to investigating water treatment applications with periodically related hydrogenation metals, e.g., $\mathrm{Rh}, \mathrm{Ru}, \mathrm{Pt}$ and Ir, which have seen many advances in other areas of catalytic science, including organic synthesis [31], biomass valorization [32], and vehicle exhaust gas conversion [33]. 
In recent screening studies by the Pereira and Neves team [34-38], several hydrogenation metals were evaluated for $\mathrm{BrO}_{3}{ }^{-}$and $\mathrm{NO}_{3}{ }^{-}$reduction, and Pd-based catalysts were still reported as having the highest activity. However, our group recently found that a $\mathrm{Rh} / \mathrm{C}$ catalyst exhibited substantially higher activity than $\mathrm{Pd} / \mathrm{C}$ for $\mathrm{ClO}_{3}{ }^{-}$reduction in acidic solution [39]. In literature, $\mathrm{Rh} / \mathrm{Al}_{2} \mathrm{O}_{3}$ [40-42] and $\mathrm{Pt} / \mathrm{C}$ [43] also exhibit unique activities, such as hydrodefluorination, that the corresponding Pd-based catalysts do not. These findings suggest that other hydrogenation metals besides Pd may have unique catalyst attributes that could benefit individual water treatment applications and therefore deserve renewed attention.

Herein we report results of a series of catalytic water treatment experiments comparing the activities of alternative platinum group metals (supported on activated carbon or alumina) for reduction of four oxyanion contaminants with a broad range of chemical reactivity $\left(\mathrm{BrO}_{3}{ }^{-}>>\right.$ $\left.\mathrm{ClO}_{3}{ }^{-}>\mathrm{NO}_{3}^{-}>>\mathrm{ClO}_{4}{ }^{-}\right) . \mathrm{Rh}$ exhibits substantially higher activity than $\mathrm{Pd}$ during reduction of $\mathrm{BrO}_{3}{ }^{-}, \mathrm{ClO}_{3}{ }^{-}$and $\mathrm{NO}_{3}{ }^{-}$. Ru, with a substantially lower cost compared to the other four metals ( $\mathrm{Pd}, \mathrm{Rh}, \mathrm{Pt}$ and Ir), shows unique $\mathrm{pH}$ insensitivity and the highest activity for $\mathrm{ClO}_{3}{ }^{-}$and $\mathrm{NO}_{3}{ }^{-}$ reduction at circumneutral $\mathrm{pH}$ conditions. All five metals are also able to reduce $\mathrm{ClO}_{4}{ }^{-}$when combined with $\mathrm{Re}$ species as bimetallic $\mathrm{Re}-\mathrm{M} / \mathrm{C}$ catalysts. Cross comparison of multiple oxyanion substrates and metals reveals new mechanistic insights and suggest new directions to develop novel catalysts for challenging water contaminants. 


\section{EXPERIMENTAL SECTION}

\subsection{Chemicals and Materials}

Unless otherwise specified, all chemicals and metal catalysts (nominal $5 \mathrm{wt} \%$ or $1 \mathrm{wt} \%$ hydrogenation metal nanoparticles dispersed on activated carbon and alumina supports) were purchased from Sigma-Aldrich or Alfa-Aesar. Detailed catalyst information and characterization data are shown in Table 1 . The $\mathrm{Ru} / \mathrm{Al}_{2} \mathrm{O}_{3}$ catalyst required a pretreatment (1 atm $\mathrm{H}_{2}$ flow in a tube furnace under $350{ }^{\circ} \mathrm{C}$ for $2 \mathrm{~h}$ ) for metal reduction and activation of oxyanion reduction activity [44]. Aqueous solutions were prepared using deionized (DI) water (resistivity 18.2 $\mathrm{M} \Omega \cdot \mathrm{cm}) . \mathrm{H}_{2}$ gas (99.9999\% UHP, Matheson) was used for catalytic reactions.

\subsection{Catalytic reduction of oxyanion contaminants}

2.2.1 Bromate $\left(\mathrm{BrO}_{3}\right)$. In a 50-mL pear-shaped flask (round bottom, $24 / 40$ joint), a magnetic stir bar, $5 \mathrm{mg}$ of catalyst (dry weight basis), and $50 \mathrm{~mL}$ of DI water were added and sonicated for 1 min to make a $0.1 \mathrm{~g} \mathrm{~L}^{-1}$ catalyst suspension. A rubber stopper loaded with two 16 gauge stainless needles capped the flask. $\mathrm{H}_{2}$ was sparged through one needle below the liquid surface, and the head space was open to the atmosphere through another needle above the liquid surface. All batch reactions were conducted under $1 \mathrm{~atm} \mathrm{H}_{2}$ at room temperature $\left(20-22^{\circ} \mathrm{C}\right)$. The solution pH was adjusted by $1 \mathrm{mM} \mathrm{HCl}(\mathrm{pH} 3.0), 0.5 \mathrm{mM} \mathrm{Na}_{2} \mathrm{HPO}_{4}$ plus $0.5 \mathrm{mM} \mathrm{NaH}_{2} \mathrm{PO}_{4}(\mathrm{pH} 7.2)$, or $0.5 \mathrm{mM} \mathrm{NaHCO}$ plus $0.5 \mathrm{mM} \mathrm{Na}_{2} \mathrm{CO}_{3}(\mathrm{pH}$ 10.3). Tests showed that these buffers were sufficient to maintain the $\mathrm{pH}$ for $\mathrm{BrO}_{3}{ }^{-}$and $\mathrm{ClO}_{3}{ }^{-}$reductions. After the suspension was presparged for $1 \mathrm{~h}$ to pre-reduce any surface oxides present on the immobilized metal nanoparticles, the reaction was initiated by adding $1 \mathrm{~mL}$ of the $50 \mathrm{mM} \mathrm{NaBrO}_{3}$ stock solution $\left(\mathrm{C}_{0}=1 \mathrm{mM}\right)$. For the rapid $\mathrm{BrO}_{3}{ }^{-}$reduction reactions, a high $\mathrm{H}_{2}$ flow rate $\left(\sim 100 \mathrm{~mL} \mathrm{~min}{ }^{-1}\right)$ was necessary to 
observe pseudo-first-order kinetics in the batch experiments. Samples were collected at periodic time intervals using a 3-mL syringe introduced through the $\mathrm{H}_{2}$ outlet needle, and the collected aliquot was immediately filtered $(0.45-\mu \mathrm{m}$ nylon membrane) to quench the reaction before subsequent analysis of the filtrate sample.

2.2.2 Chlorate $\left(\mathrm{ClO}_{3}\right)$. The reaction setup was the same as for $\mathrm{BrO}_{3}{ }^{-}$reduction, except that the catalyst loading in the suspension was increased to $0.5 \mathrm{~g} \mathrm{~L}^{-1}$ because initial tests showed this oxyanion to generally exhibit lower reactivity with the catalysts. $\mathrm{H}_{2}$ gas flow rates higher than $\sim 20 \mathrm{~mL} \mathrm{~min}{ }^{-1}$ did not increase reaction rates. An aliquot of $\mathrm{KClO}_{3}$ stock solution $(50 \mathrm{mM}, 1 \mathrm{~mL})$ was added to the reactor to initiate individual batch reactions with $\mathrm{C}_{0}=1 \mathrm{mM}$.

2.2.3 Nitrate $\left(\mathrm{NO}_{3}{ }^{-}\right)$. The reaction setup was the same as for $\mathrm{ClO}_{3}{ }^{-}$reduction, and a $\mathrm{NaNO}_{3}$ stock solution $(50 \mathrm{mM})$ was added to initiate batch reactions with $\mathrm{C}_{0}=1 \mathrm{mM}$. The $\mathrm{pH}$ was stabilized using higher buffer concentrations $\left[1 \mathrm{mM} \mathrm{HCl}\right.$ plus $10 \mathrm{mM} \mathrm{H}_{3} \mathrm{PO}_{4}$ (pH pre-adjusted with $\mathrm{NaOH}$ to 3.0), $5 \mathrm{mM} \mathrm{Na}_{2} \mathrm{HPO}_{4}$ plus $5 \mathrm{mM} \mathrm{NaH}_{2} \mathrm{PO}_{4}$ (pH 7.2), or $5 \mathrm{mM} \mathrm{NaHCO}_{3}$ plus 5 $\mathrm{mM} \mathrm{Na} \mathrm{CO}_{3}\left(\mathrm{pH}\right.$ 10.3)] because $\mathrm{NO}_{3}{ }^{-}$reduction consumes one [ $\mathrm{N}_{2}$ product, Eq. (1)] or up to two equivalents of $\mathrm{H}^{+}\left[\mathrm{NH}_{4}{ }^{+}\right.$product, Eq. (2)] [14].

$$
\begin{aligned}
& \mathrm{NO}_{3}{ }^{-}+2.5 \mathrm{H}_{2}+\mathrm{H}^{+} \rightarrow 0.5 \mathrm{~N}_{2}+3 \mathrm{H}_{2} \mathrm{O} \\
& \mathrm{NO}_{3}{ }^{-}+4 \mathrm{H}_{2}+2 \mathrm{H}^{+} \rightarrow \mathrm{NH}_{4}{ }^{+}+3 \mathrm{H}_{2} \mathrm{O}
\end{aligned}
$$

2.2.4 Preparation of $\mathrm{Re}-\mathrm{M} / \mathrm{C}$ and reduction of perchlorate $\left(\mathrm{ClO}_{4}{ }^{-}\right)$. In a 50 -mL pear shape flask, a magnetic stir bar, $50 \mathrm{mg}$ of M/C catalyst and $25 \mathrm{~mL}$ of DI water (pH pre-adjusted to 3.0 using $1 \mathrm{mM} \mathrm{HCl}$ ) were added and sonicated for 1 min to yield a $2.0 \mathrm{~g} \mathrm{~L}^{-1}$ catalyst suspension. A $\mathrm{NH}_{4} \mathrm{ReO}_{4}$ stock solution (5000 ppm as $\mathrm{Re}, 0.5 \mathrm{~mL}$ ) was added to the $\mathrm{M} / \mathrm{C}$ catalyst suspension to reductively immobilize $\operatorname{Re}\left(\mathrm{C}_{\mathrm{T}}=100 \mathrm{ppm}\right)$ into the porous carbon support matrix under $\mathrm{H}_{2}$ 
sparging (flow rate $\sim 10 \mathrm{~mL} \mathrm{~min}^{-1}$ ). The immobilization process was monitored by measuring dissolved $\mathrm{ReO}_{4}{ }^{-}$in filtered water samples with ion chromatography until concentrations were below detection [14]. Overnight sparging with $\mathrm{H}_{2}$ led to complete immobilization of Re and yielded bimetallic catalysts containing $5 \mathrm{wt} \%$ Re. Reactions with $\mathrm{ClO}_{4}{ }^{-}$were then initiated by adding an aliquot of $\mathrm{NaClO}_{4}$ stock solution $(200 \mathrm{mM}, 0.625 \mathrm{~mL})$ to the suspension $\left(\mathrm{C}_{0}=5 \mathrm{mM}\right)$. Samples were collected and filtered using the same procedures described above.

\subsection{Water sample analysis}

The concentrations of $\mathrm{BrO}_{3}{ }^{-}, \mathrm{Br}^{-}, \mathrm{ClO}_{3}{ }^{-}, \mathrm{Cl}^{-}$, and $\mathrm{NO}_{3}{ }^{-}$were determined by a Dionex ICS-3000 ion chromatography system $(25-\mu \mathrm{L}$ injection loop and a suppressed conductivity detector). An IonPac AS19 column maintained at $30{ }^{\circ} \mathrm{C}$ was used as the stationary phase and $10 \mathrm{mM} \mathrm{KOH}$ at $1.0 \mathrm{~mL} \mathrm{~min}{ }^{-1}$ was the eluent. The concentrations of $\mathrm{ClO}_{4}{ }^{-}$and $\mathrm{ReO}_{4}{ }^{-}$were analyzed by a Dionex ICS-2000 ion chromatography system $(25-\mu \mathrm{L}$ injection loop and a suppressed conductivity detector). An IonPac AS16 column maintained at $30{ }^{\circ} \mathrm{C}$ was used as the stationary phase and 65 $\mathrm{mM} \mathrm{KOH}$ at $1.2 \mathrm{~mL} \min ^{-1}$ was the eluent.

\subsection{Catalyst characterization}

Specific surface area (BET method) and average pore size (BJH method) of the catalyst support materials were measured by $\mathrm{N}_{2}$ physisorption with a Micromeritics ASAP 2020 analyzer. Dispersion of the hydrogenation metals was determined by chemisorption based on literature methods [45-47] with a Micromeritics AutoChem II analyzer equipped with a thermal conductivity detector. Results of physisorption and chemisorption measurements are summarized in Table 1. To determine surface zeta potentials of selected catalysts under varied $\mathrm{pH}$ and the $\mathrm{H}_{2}$ atmosphere, catalyst suspensions $\left(0.5 \mathrm{~g} \mathrm{~L}^{-1}\right)$ containing different $\mathrm{pH}$ buffers (as described in 
2.2.1) were sparged with $1 \mathrm{~atm} \mathrm{H}_{2}$ for $30 \mathrm{~min}$, and immediately transferred into an anaerobic glovebox $\left(97 \% \mathrm{~N}_{2}, 3 \% \mathrm{H}_{2}\right.$; Coy Laboratories). An aliquot of suspension was then transferred into a cuvette and sealed with the plastic cap before analyzing for zeta potential (Malvern Zetasizer Nano ZS).

\subsection{Kinetic data analysis}

Under the reaction conditions described above, reduction of all oxyanion contaminants generally followed a pseudo-first-order rate law for at least two half-lives (i.e., $75 \%$ decay). The initial turnover frequency $\left(\mathrm{TOF}_{0}, \mathrm{~min}^{-1}\right)$, which represents the number of oxyanion molecules reduced per surface metal site per minute, was calculated by Eq. (3) [19]:

$$
T O F_{0}=\frac{k C_{0}}{C_{\text {surface metal }}}=\frac{k C_{0} M_{\text {metal }}}{C_{\text {total metal }} D_{\text {metal }}} \quad \text { Eq. (3) }
$$

where $k$ is the measured pseudo-first-order rate constant $\left(\mathrm{min}^{-1}\right)$ for oxyanion reduction in the batch reaction, $C_{0}$ is the initial oxyanion concentration $\left(\mathrm{mol} \mathrm{L}^{-1}\right), C_{\text {surface metal }}$ is the concentration of surface metal in the catalyst suspension $\left(\mathrm{mol} \mathrm{L}^{-1}\right), M_{\text {metal }}$ is the molar mass of metal element $\left(\mathrm{g} \mathrm{mol}^{-1}\right), C_{\text {total metal }}$ is the total concentration of metal loaded in the catalyst suspension $\left(\mathrm{g} \mathrm{L}^{-1}\right)$, and $D_{\text {metal }}$ is the metal dispersion on the catalyst support material (Table 1), representing the fraction of metal atoms exposed on the surface of the dispersed metal nanoparticles. 


\section{RESULTS AND DISCUSSION}

\subsection{Catalytic reduction of bromate}

Figure 1a shows catalytic reduction of bromate $\left(\mathrm{BrO}_{3}{ }^{-}\right)$at $\mathrm{pH} 7.2$ by the five activated carbon supported metal catalysts $\left[\mathrm{M} / \mathrm{C}, 0.1 \mathrm{~g} \mathrm{~L}^{-1}\right.$ catalyst loading with nominal $5 \mathrm{wt} \%(\mathrm{Pd}, \mathrm{Pt}, \mathrm{Rh}, \mathrm{Ru})$ or $1 \mathrm{wt} \%$ (Ir) of each metal]. A good mass balance between $\mathrm{BrO}_{3}{ }^{-}$and $\mathrm{Br}^{-}$is obtained for each catalyst (Figure S1), demonstrating complete $\mathrm{BrO}_{3}{ }^{-}$reduction with negligible accumulation of $\mathrm{BrO}_{\mathrm{x}}{ }^{-}(\mathrm{x}<3)$ intermediates [Eq. (4)].

$$
\mathrm{BrO}_{3}^{-}+3 \mathrm{H}_{2} \rightarrow \mathrm{Br}^{-}+3 \mathrm{H}_{2} \mathrm{O} \quad \text { Eq. (4) }
$$

Comparing the observed $\mathrm{BrO}_{3}{ }^{-}$reduction profiles shows that $\mathrm{Rh} / \mathrm{C}$ is substantially more active than the other four $\mathrm{M} / \mathrm{C}$ catalysts. At the catalyst loading of $0.1 \mathrm{~g} \mathrm{~L}^{-1}$, the reduction of $1 \mathrm{mM}$ $\mathrm{BrO}_{3}{ }^{-}$is complete within $5 \mathrm{~min}$. The activity of $\mathrm{Rh} / \mathrm{C}$ is much higher than most supported hydrogenation metal catalysts reported to date when compared on a metal mass-normalized basis [34, 36-38, 48, 49]. Since the metal dispersion of individual catalysts differ (Table 1), the activities of hydrogenation metals are further compared using initial turnover frequency values $\left[\mathrm{TOF}_{0}\right.$, Eq. (3)]. As shown in Table 2, Rh/C exhibited significantly higher $\mathrm{TOF}_{0}$ than other catalysts at $\mathrm{pH}$ 7.2. Although the apparent reactivity of $\mathrm{Ir} / \mathrm{C}$ with $\mathrm{BrO}_{3}{ }^{-}$is slightly lower than that of $\mathrm{Pd} / \mathrm{C}$ (Figure 1a), Ir/C exhibited the second highest $\mathrm{TOF}_{0}$. Thus, the catalysts incorporating the two Group 9 metals, $\mathrm{Rh}$ and $\mathrm{Ir}$, show the highest activity for $\mathrm{BrO}_{3}{ }^{-}$reduction at neutral $\mathrm{pH}$ conditions that are highly relevant for water treatment systems.

Acidic $\mathrm{pH}$ conditions have been previously reported to accelerate $\mathrm{BrO}_{3}{ }^{-}$reduction by $\mathrm{Pd}$ catalysts $[20,48]$. To examine if this trend extends to other hydrogenation metals, $\mathrm{BrO}_{3}{ }^{-}$ reduction by all five $\mathrm{M} / \mathrm{C}$ catalysts was also measured at $\mathrm{pH} 3.0$. Results from these experiments 
(Table 2, Figure S2a) show that catalysts incorporating the two Group 10 metals, Pd and Pt, exhibit significant $\mathrm{pH}$ dependence, with $\mathrm{TOF}_{0}$ increasing by more than an order of magnitude when $\mathrm{pH}$ is lowered from 7.2 to 3.0. In comparison, the catalysts incorporating Group 9 ( $\mathrm{Rh}$ and Ir) and Group $8(\mathrm{Ru})$ metals show less activity change when $\mathrm{pH}$ is lowered. $\mathrm{TOF}_{0}$ for $\mathrm{Rh} / \mathrm{C}$ and $\mathrm{Ru} / \mathrm{C}$ decrease by $35-40 \%$, and $\mathrm{Ir} / \mathrm{C}$ increases 3-fold when the $\mathrm{pH}$ is lowered from 7.2 to 3.0.

\subsection{Catalytic reduction of chlorate}

Results for catalytic reduction of chlorate $\left(\mathrm{ClO}_{3}{ }^{-}\right)$by $\mathrm{M} / \mathrm{C}$ at $\mathrm{pH} 7.2$ are shown in Figure 1b. In comparison to $\mathrm{BrO}_{3}{ }^{-}, \mathrm{ClO}_{3}{ }^{-}$is much more inert to reduction (note that the suspension catalyst loading used in the experiments was increased to $0.5 \mathrm{~g} \mathrm{~L}^{-1}$ ). Like $\mathrm{BrO}_{3}{ }^{-}$, a good mass balance with $\mathrm{ClO}_{3}{ }^{-}$and $\mathrm{Cl}^{-}$(Figure S3) is observed during reactions, consistent with the following reaction [Eq. (5)] and confirming negligible accumulation of $\mathrm{ClO}_{\mathrm{x}}{ }^{-}(\mathrm{x}<3)$ intermediates.

$$
\mathrm{ClO}_{3}^{-}+3 \mathrm{H}_{2} \rightarrow \mathrm{Cl}^{-}+3 \mathrm{H}_{2} \mathrm{O} \quad \text { Eq. (5) }
$$

The highest apparent reactivity with $\mathrm{ClO}_{3}{ }^{-}$is observed with $\mathrm{Ru} / \mathrm{C}$, a Group 8 metal, and the resulting $\mathrm{TOF}_{0}\left(6.0 \mathrm{~min}^{-1}\right)$ is substantially higher than catalysts incorporating the other four Group 9 and 10 metals (Table 2), due, in part, to the low dispersion of Ru nanoparticles on the carbon support. $\mathrm{TOF}_{0}$ values measured for the two Group 9 metals $\left(0.17 \mathrm{~min}^{-1}\right.$ for $\mathrm{Rh}$ and 0.061 $\min ^{-1}$ for Ir) are higher than those observed for the two Group 10 metals $\left(<0.01 \mathrm{~min}^{-1}\right.$ for Pd and $\mathrm{Pt}$ ). Thus, for neutral $\mathrm{pH}$ conditions, periodic trends suggest that $\mathrm{ClO}_{3}{ }^{-}$reactivity follows Group $8>>$ Group $9>>$ Group 10 metals.

Comparing $\mathrm{pH}$ dependences for $\mathrm{ClO}_{3}{ }^{-}$reactions with the different $\mathrm{M} / \mathrm{C}$ reveals some other interesting trends. Catalysts incorporating the Group 9 and 10 metals show significantly 
enhanced reactivity with $\mathrm{ClO}_{3}{ }^{-}$under acidic $\mathrm{pH}$ conditions compared to $\mathrm{pH} 7.2$ (Figure $\mathbf{S 2 b}$ and Table 2), whereas reactions are inhibited under these conditions for $\mathrm{Ru}$, the Group 8 metal. At $\mathrm{pH} 3.0, \mathrm{Rh} / \mathrm{C}$ is the most active catalyst for $\mathrm{ClO}_{3}{ }^{-}$reduction $\left(\mathrm{TOF}_{0}\right.$ increases from $0.17 \mathrm{~min}^{-1}$ at $\mathrm{pH} 7.2$ to $6.7 \mathrm{~min}^{-1}$ ). A mirror trend is observed for $\mathrm{Ru} / \mathrm{C}$, where $\mathrm{TOF}_{0}$ decreases from $6.0 \mathrm{~min}^{-1}$ at $\mathrm{pH} 7.2$ to $0.11 \mathrm{~min}^{-1}$ at $\mathrm{pH}$ 3.0. The unique $\mathrm{pH}$ dependence observed for $\mathrm{Ru} / \mathrm{C}$ suggests different rate-controlling surface reaction mechanisms for this catalyst compared to those incorporating Group 9 and 10 metals.

\subsection{Catalytic reduction of nitrate}

Of the catalysts examined, only $\mathrm{Rh} / \mathrm{C}$ and $\mathrm{Ru} / \mathrm{C}$ show meaningful reactivity with the more recalcitrant nitrate ion $\left(\mathrm{NO}_{3}{ }^{-}\right)$in $0.5 \mathrm{~g} \mathrm{~L}^{-1}$ catalyst suspensions monitored for $4 \mathrm{~h}$. As shown in Table 2 (and Figure S4), Ru shows much higher activity than Rh, and both metals exhibit enhanced activities when $\mathrm{pH}$ is reduced from 7.2 to 3.0. The observed product of $\mathrm{NO}_{3}{ }^{-}$reduction by these two metals under the test conditions is mostly $\mathrm{NH}_{3} / \mathrm{NH}_{4}{ }^{+}$[Eq. (2)] rather than the desired $\mathrm{N}_{2}$ [Eq. (1)]. Nevertheless, results show that monometallic $\mathrm{Rh}$ and $\mathrm{Ru}$ catalysts are capable of reducing $\mathrm{NO}_{3}{ }^{-}$without the need for secondary promoter metals (e.g., $\mathrm{In}, \mathrm{Cu}, \mathrm{Sn}$, and $\mathrm{Re}$ ) used to activate $\mathrm{Pd}$ catalysts towards $\mathrm{NO}_{3}{ }^{-}$reduction $[14,18,25]$. Motivated by the low

market price of $\mathrm{Ru}\left(\$ 1.4 \mathrm{~g}^{-1}\right)$ in comparison to the other metals ( $\$ 17$ to $\$ 38 \mathrm{~g}^{-1}$ ) (Table S1), an in-depth study of Ru-catalyzed $\mathrm{NO}_{3}{ }^{-}$and $\mathrm{NO}_{2}{ }^{-}$reduction by our team was undertaken and reported separately [44].

\subsection{Effect of metal catalyst support materials}

We also examined reactions of the three tri-oxy anions with $\mathrm{Pd}, \mathrm{Pt}, \mathrm{Rh}$, and $\mathrm{Ru}$ supported on porous alumina $\left(\mathrm{M} / \mathrm{Al}_{2} \mathrm{O}_{3}\right)$, another common catalyst support material, and found generally the 
same reactivity trends observed for the $\mathrm{M} / \mathrm{C}$ catalysts. Alumina is unstable under acidic $\mathrm{pH}$ conditions, so reactivity was only compared with $\mathrm{M} / \mathrm{C}$ at $\mathrm{pH}$ 7.2. Compared to activated carbon support materials, the alumina supports generally have an order of magnitude lower specific surface areas and two times larger pore average size (Table 1). As shown in Figure 2 and Table 2, $\mathrm{M} / \mathrm{Al}_{2} \mathrm{O}_{3}$ catalysts generally exhibit similar activity compared to the corresponding $\mathrm{M} / \mathrm{C}$. Still, the highest activity for $\mathrm{BrO}_{3}{ }^{-}$reduction at $\mathrm{pH} 7.2$ is observed with both $\mathrm{Rh} / \mathrm{C}$ and $\mathrm{Rh} / \mathrm{Al}_{2} \mathrm{O}_{3}$, and the highest activity for $\mathrm{ClO}_{3}{ }^{-}$and $\mathrm{NO}_{3}{ }^{-}$reduction is observed with both $\mathrm{Ru} / \mathrm{C}$ and $\mathrm{Ru} / \mathrm{Al}_{2} \mathrm{O}_{3}$. These similar trends suggest that activity differences among the catalysts primarily originate from the chemical nature of the immobilized metal nanoparticles, and the effects of the support materials may be minor.

\subsection{Catalytic reduction of perchlorate}

For the tetra-oxyanion perchlorate $\left(\mathrm{ClO}_{4}{ }^{-}\right)$, the most inert of the target oxyanions examined, no reaction is observed using any of the monometallic catalysts (Table S2). We previously reported on preparation of bimetallic $\mathrm{Re}-\mathrm{Pd} / \mathrm{C}$ catalysts that are able to reduce aqueous $\mathrm{ClO}_{4}{ }^{-}$because the immobilized surface oxorhenium(V) species [from the catalytic reduction of oxorhenium(VII) with $\mathrm{Pd} / \mathrm{C}$, Eq. (6)] are able to abstract the most challenging oxygen atom, via oxygen atom transfer (OAT) reaction, converting $\mathrm{ClO}_{4}{ }^{-}$to $\mathrm{ClO}_{3}{ }^{-}$[Eq. (7)], which is further reduced to $\mathrm{Cl}^{-}$[Eq. (8)] by OAT with $\mathrm{Re}^{\mathrm{V}}$ or directly by reaction with hydrogenation nanoparticles (Figure 3a) [39, $50,51]$.

$$
\begin{gathered}
\operatorname{Re}^{\mathrm{VII}}(\mathrm{O})_{\mathrm{n}}+\mathrm{H}_{2} \rightarrow \operatorname{Re}^{\mathrm{V}}(\mathrm{O})_{\mathrm{n}-1}+\mathrm{H}_{2} \mathrm{O} \\
\mathrm{ClO}_{4}{ }^{-}+\operatorname{Re}^{\mathrm{V}}(\mathrm{O})_{\mathrm{n}-1} \rightarrow \mathrm{ClO}_{3}{ }^{-}+\operatorname{Re}^{\mathrm{VII}}(\mathrm{O})_{\mathrm{n}}
\end{gathered}
$$




$$
\mathrm{ClO}_{3}^{-}+3 \mathrm{H}_{2} \rightarrow \rightarrow \rightarrow \mathrm{Cl}^{-}+3 \mathrm{H}_{2} \mathrm{O} \quad \text { Eq. (8) }
$$

And thus the overall reaction is

$$
\mathrm{ClO}_{4}^{-}+4 \mathrm{H}_{2} \rightarrow \mathrm{Cl}^{-}+4 \mathrm{H}_{2} \mathrm{O} \quad \text { Eq. (9) }
$$

In order to assess the dependence of $\mathrm{ClO}_{4}{ }^{-}$reduction on the other four hydrogenation metals, we followed the same approach for bimetallic catalyst synthesis $[14,52]$ to prepare $\mathrm{Re}-\mathrm{M} / \mathrm{C}$ catalysts using each of the $\mathrm{M} / \mathrm{C}$ catalysts discussed already. Figure $\mathbf{3 b}$ shows the reactivity of 5 $\mathrm{mM} \mathrm{ClO}_{4}{ }^{-}$with $2 \mathrm{~g} \mathrm{~L}^{-1}$ of each $\mathrm{Re}^{-} \mathrm{M} / \mathrm{C}$ catalyst. The apparent reactivity of the bimetallic catalysts follows $\mathrm{Re}-\mathrm{Pd} / \mathrm{C}>\mathrm{Re}-\mathrm{Ru} / \mathrm{C}>\mathrm{Re}-\mathrm{Rh} / \mathrm{C}>\mathrm{Re}-\mathrm{Ir} / \mathrm{C}>\mathrm{Re}-\mathrm{Pt} / \mathrm{C}$. Mechanistic interpretation of this trend is unclear at this time. This is complicated by the fact that previous work shows that the rate of $\mathrm{ClO}_{4}{ }^{-}$reduction by OAT reactions is more heavily influenced by the speciation of the immobilized Re species than the identity of the hydrogenation metal $[53,54]$. Nevertheless, these results demonstrate that all five hydrogenation metals are capable of sustaining the redox turnover of surface Re species [Eqs. (6) and (7)] required to catalyze the OAT reaction with $\mathrm{ClO}_{4}{ }^{-}$(turn over number, TON $=38$ for each Re atom to fully reduce $5 \mathrm{mM}$ $\mathrm{ClO}_{4}{ }^{-}$to $\mathrm{Cl}^{-}$with the catalyst loadings used in the experiment).

\subsection{Mechanistic insights from metal and $\mathrm{AO}_{3}{ }^{-}$reactivity cross comparisons}

Comparison of observed reactivity trends among the platinum group metals and trioxyanion substrates $\left(\mathrm{AO}_{3}{ }^{-}\right)$reveals new insights on the controlling reaction mechanisms. First, since the optimum metals for the reduction of $\mathrm{BrO}_{3}{ }^{-}$( $\mathrm{Rh}$ at $\mathrm{pH}$ 7.2) and $\mathrm{ClO}_{3}{ }^{-}(\mathrm{Ru}$ at $\mathrm{pH}$ 7.2) differ, the oxyanion substrates should have direct interactions with metal nanoparticle surfaces to undergo reduction (Figure 4a). If the oxyanions mainly react with dissociated atomic hydrogen that is 
"spilled" away from the metal nanoparticles (Figure 4b) [55, 56], the order of catalytic activity for the five metals toward the three oxyanions may be expected to be more similar. However, the measured activity order is $\mathrm{Rh}>\mathrm{Ir}>\mathrm{Pt} \sim \mathrm{Pd} \sim \mathrm{Ru}$ for $\mathrm{BrO}_{3}{ }^{-}$reduction at $\mathrm{pH}$ 7.2, and $\mathrm{Ru} \gg>\mathrm{Rh}>$ $\mathrm{Ir}>\mathrm{Pt}>\mathrm{Pd}$ for $\mathrm{ClO}_{3}{ }^{-}$reduction at $\mathrm{pH} 7.2$ (Table 2). In addition, we note that the observed activity trends are different from those previously report by Restivo et al. [34], where the M/C catalysts were prepared in the researchers' own laboratory and exhibited much lower $\mathrm{BrO}_{3}{ }^{-}$ reduction activity (e.g., $>15 \mathrm{~min}$ was required to completely reduce $0.078 \mathrm{mM} \mathrm{BrO}_{3}^{-}$by $2 \mathrm{~g} \mathrm{~L}^{-1}$ of $1 \mathrm{wt} \% \mathrm{M} / \mathrm{C}$ catalysts) than our experimental results (e.g., $5 \mathrm{~min}$ to completely reduce $1.0 \mathrm{mM}$ $\mathrm{BrO}_{3}{ }^{-}$by $\left.0.1 \mathrm{~g} \mathrm{~L}^{-1} 5 \mathrm{wt} \% \mathrm{Rh} / \mathrm{C}\right)$. We note that the differences of $\mathrm{BrO}_{3}{ }^{-}$concentration and catalyst loading have overweighed the effect of metal loading. Explanation of the discrepancies of catalyst activity in different reports, if necessary, would require substantial amount of catalyst characterization and comparison. It is probable that critical catalytic properties of individual metals might have not be revealed when using a uniform catalyst preparation recipe for all metals (i.e., the recipes were not optimized for individual metal) by the Pereira and Neves team.

Nevertheless, results suggest that the mechanistic interpretation, which might be used as design rationale for future catalyst development work, should be considered with caution. Restivo et al. observed $\mathrm{Pt}$ and $\mathrm{Ru}$ to be the most active metals for $\mathrm{BrO}_{3}{ }^{-}$reduction, and this observation was correlated with the hydrogen chemisorption energy on each metal using the Sabatier principle [34]. However, based on the activity of Rh and Ir in the current study, we propose that hydrogen chemisorption energy might not necessarily be the key parameter controlling reactivity of different metals with $\mathrm{BrO}_{3}{ }^{-}$, and that the interaction between oxyanion substrates and different metal surfaces should also be considered. 
Second, the $\mathrm{pH}$ responses of the five metals are also different. For $\mathrm{BrO}_{3}{ }^{-}$reduction, the $\mathrm{pH}$ responses of $\mathrm{Rh}$ and $\mathrm{Ru}$ contrast those of $\mathrm{Pd}$, $\mathrm{Pt}$ and $\mathrm{Ir}$ (Table 2). Also, the same $\mathrm{Rh} / \mathrm{C}$ catalyst exhibits differing $\mathrm{pH}$ dependence for $\mathrm{BrO}_{3}{ }^{-}$reduction compared to $\mathrm{ClO}_{3}{ }^{-}$and $\mathrm{NO}_{3}{ }^{-}$reduction (Figure 5, activity presented in apparent rate constants normalized by the mass of M/C catalysts), even though the three oxyanions carry the same -1 charge in solutions between $\mathrm{pH} 3.0$ and 10.3. In comparison, $\mathrm{Ru} / \mathrm{C}$ catalyst did not show a simple trend of $\mathrm{pH}$ dependence. Zeta potentials of $\mathrm{Rh} / \mathrm{C}$ and $\mathrm{Ru} / \mathrm{C}$ under variable $\mathrm{pH}$ (with a $\mathrm{H}_{2}$ atmosphere [20,52]) were measured and results are shown in Figure 6. Although the zeta potentials of both catalysts are significantly increased when the $\mathrm{pH}$ decreases from 7.2 to 3.0, the $\mathrm{BrO}_{3}{ }^{-}$reduction by $\mathrm{Rh} / \mathrm{C}$ and $\mathrm{Ru} / \mathrm{C}$ (Figure 6a) as well as the $\mathrm{ClO}_{3}{ }^{-}$reduction by $\mathrm{Ru} / \mathrm{C}$ (Figure 6b) are not accelerated. Previous reports attribute slower rates of $\mathrm{BrO}_{3}{ }^{-}$reduction by $\mathrm{Pd}$ catalysts at higher $\mathrm{pH}$ to increased negative surface charge and the resulting unfavorable electrostatic interactions between the surface and the negatively charged oxyanions $[20,57]$. Here, results demonstrate that a more positively charged support at lower $\mathrm{pH}$ does not necessarily increase rates of oxyanion reduction for all $\mathrm{M} / \mathrm{C}$. Hence, the intrinsic reactivity of metals may outweigh the effects of catalyst surface charge. Therefore, the priority of designing an oxyanion reduction catalyst should consider the selection of active metal according to the characteristics of oxyanion substrates and reaction conditions (e.g., solution $\mathrm{pH}$ ).

\subsection{Outlook in catalyst development and application}

In this study, four platinum group metals, which have been largely overlooked during the development of Pd-based water treatment catalysts, exhibit much higher or at least similar performance in comparison to $\mathrm{Pd}$, in terms of catalytic turnover frequency, $\mathrm{pH}$ dependence, and oxyanion substrate scope. Specifically, $\mathrm{Ru}$ shows outstanding activity for $\mathrm{ClO}_{3}{ }^{-}$and $\mathrm{NO}_{3}{ }^{-}$ reduction over a wide $\mathrm{pH}$ range, and the price of $\mathrm{Ru}$ is more than an order of magnitude lower 
than the other four metals (Table S1). Thus, lower cost and more sustainable reductive catalytic technologies $[15,16]$ may be achieved by developing Ru-based multi-functional materials. Moreover, our research group has developed highly stable $\mathrm{ClO}_{4}{ }^{-}$reduction catalysts based on $\mathrm{Rh}$ rather than $\mathrm{Pd}$, because the former could rapidly scavenge $\mathrm{ClO}_{\mathrm{x}}{ }^{-}$intermediates that can deactivate Re complex reaction sites $[39,54]$. Results from this study are expected to initiate the development of new catalysts for a variety of water treatment scenarios.

Various factors such as size and morphology of both the metal nanoparticles and the support materials can also influence the reactivity of platinum group metals [19, 57], but the effects are generally less pronounced compared to the effects of metal identity (e.g., $\mathrm{Pd}$ versus $\mathrm{Rh}$ in $\mathrm{ClO}_{3}{ }^{-}$ reduction, or $\mathrm{Pd}$ versus $\mathrm{Ru}$ in $\mathrm{NO}_{3}{ }^{-}$reduction) as demonstrated in this study. Computational studies $[19,58]$ are also needed to provide detailed theoretical insights into these metal-specific effects and metal-substrate interactions. We emphasize that research priority should be given to further examining novel activity of these previously overlooked metals in water treatment applications, such as (1) exploring multi-functional activities in treating various emerging and challenging contaminants (e.g., nitro [59], fluoro [40-43] and polychloro [60, 61] compounds), and (2) rational development of catalyst formulation and engineering processes to apply these metals for practical water treatment. 


\section{CONCLUSION}

Four platinum group metals $(\mathrm{Ru}, \mathrm{Rh}, \mathrm{Ir}$, and $\mathrm{Pt})$, largely overlooked in the development of water treatment catalysts compared to $\mathrm{Pd}$, are shown here to exhibit favorable reactivity with aqueous bromate, chlorate, nitrate and perchlorate at ambient conditions. Specifically, $\mathrm{Rh}$ and $\mathrm{Ru}$ show significant advantages over $\mathrm{Pd}$ in terms of catalytic turnover frequency, $\mathrm{pH}$ dependence, oxyanion substrate scope, or cost. Cross comparison of multiple metals and tri-oxyanion substrates suggest that some previous interpretations of the $\mathrm{pH}$ influence on catalyst reactivity should be revisited. The chemical nature of each metal element is a key factor determining the catalyst activity and adaptability to different water treatment conditions. We recommend that rational selection of metals could be one of the current priorities in the development of water treatment catalysts.

\section{SUPPLEMENTARY INFORMATION}

Additional materials as noted in the text.

\section{ACKNOWLEDGEMENT}

Financial support was provided by the National Science Foundation (CBET-1555549) and the

U.S. EPA (RD-83517401). We thank Prof. James Ranville (Colorado School of Mines) for the zeta potential measurement and Mr. Xin Xiao (Zhejiang University) for helpful discussions. 


\section{Figure captions}

Table 1. Catalyst information and characterization data.

Table 2. Intial turnover frequencies for the reaction of $1 \mathrm{mM}$ oxyanions with $\mathrm{M} / \mathrm{C}$ and $\mathrm{M} / \mathrm{Al}_{2} \mathrm{O}_{3}$.

Figure 1. Timecourse profiles with for reduction of (a) $1 \mathrm{mM} \mathrm{BrO}_{3}^{-}$by $0.1 \mathrm{~g} \mathrm{~L}^{-1} \mathrm{M} / \mathrm{C}$ catalysts and (b) $1 \mathrm{mM} \mathrm{ClO}_{3}{ }^{-}$by $0.5 \mathrm{~g} \mathrm{~L}^{-1} \mathrm{M} / \mathrm{C}$ catalysts with 1 atm $\mathrm{H}_{2}$ at $\mathrm{pH} 7.2$ and $22^{\circ} \mathrm{C}$ (nominal $5 \mathrm{wt} \%$ metal for $\mathrm{Pd}, \mathrm{Rh}, \mathrm{Ru}$, and $\mathrm{Pt} ; 1 \mathrm{wt} \%$ metal for $\mathrm{Ir}$ ).

Figure 2. Timecourse profiles with for reduction of (a) $1 \mathrm{mM} \mathrm{BrO}_{3}^{-}$by $0.1 \mathrm{~g} \mathrm{~L}^{-1} \mathrm{M} / \mathrm{Al}_{2} \mathrm{O}_{3}$ catalysts and (b) $1 \mathrm{mM} \mathrm{ClO}_{3}{ }^{-}$by $0.5 \mathrm{~g} \mathrm{~L}^{-1} \mathrm{M} / \mathrm{Al}_{2} \mathrm{O}_{3}$ catalysts with 1 atm $\mathrm{H}_{2}$ at $\mathrm{pH} 7.2$ and $22^{\circ} \mathrm{C}$ (nominal $5 \mathrm{wt} \%$ metal for all catalysts).

Figure 3. (a) Mechanisms for $\mathrm{Re}-\mathrm{M} / \mathrm{C}$ catalyst reactions with $\mathrm{ClO}_{4}{ }^{-}$and $\mathrm{ClO}_{\mathrm{x}}{ }^{-}$intermediates (x $=4,3,2$, or 1); adapted from Refs [50, 51]. (b) Reduction of $5 \mathrm{mM} \mathrm{ClO}_{4}^{-}$with $2 \mathrm{~g} \mathrm{~L}^{-1} \mathrm{Re}-\mathrm{M} / \mathrm{C}$ $(5 \mathrm{wt} \% \mathrm{Re}, 5 \mathrm{wt} \% \mathrm{M})$ bimetallic catalysts.

Figure 4. Mechanism illustrations of (a) the reduction of oxyanion substrates $\left(\mathrm{AO}_{\mathrm{x}}{ }^{-}\right)$requiring direct interaction with the hydrogenation metal nanoparticles; (b) the reaction between $\mathrm{AO}_{\mathrm{x}}{ }^{-}$and spilled over atomic hydrogen at the catalyst support surface away from the hydrogenation metal nanoparticles.

Figure 5. Catalyst loading normalized rate constants at different $\mathrm{pH}$ for the reduction of $1 \mathrm{mM}$ (a) $\mathrm{BrO}_{3}{ }^{-}$, (b) $\mathrm{ClO}_{3}{ }^{-}$and (c) $\mathrm{NO}_{3}{ }^{-}$with $\mathrm{Rh} / \mathrm{C}$ and $\mathrm{Ru} / \mathrm{C}$ catalysts. Error bars represent replicateaveraged $95 \%$ confidence intervals. "NR" indicates no reaction observed within the reaction period monitored.

Figure 6. Influence of $\mathrm{pH}$ on the zeta potential of $0.5 \mathrm{~g} \mathrm{~L}^{-1} \mathrm{Rh} / \mathrm{C}$ and $\mathrm{Ru} / \mathrm{C}$ catalysts in $\mathrm{H}_{2^{-}}$ saturated aqueous suspension at $22{ }^{\circ} \mathrm{C}$. 


\section{REFERENCE}

[1] S.A. Snyder, B.J. Vanderford, D.J. Rexing, Trace analysis of bromate, chlorate, iodate, and perchlorate in natural and bottled waters, Environ. Sci. Technol. 39 (2005) 4586-4593.

[2] R.F. Spalding, M.E. Exner, Occurrence of nitrate in groundwater-a review, J. Environ. Qual. 22 (1993) 392-402.

[3] E.T. Urbansky, Perchlorate as an environmental contaminant, Environ. Sci. Pollut. Res. 9 (2002) $187-$ 192.

[4] K. Kosaka, M. Asami, Y. Matsuoka, M. Kamoshita, S. Kunikane, Occurrence of perchlorate in drinking water sources of metropolitan area in Japan, Water Res. 41 (2007) 3474-3482.

[5] H.S. Weinberg, C.A. Delcomyn, V. Unnam, Bromate in chlorinated drinking waters: occurrence and implications for future regulation, Environ. Sci. Technol. 37 (2003) 3104-3110.

[6] R. Butler, A. Godley, L. Lytton, E. Cartmell, Bromate environmental contamination: review of impact and possible treatment, Crit. Rev. Env. Sci. Technol. 35 (2005) 193-217.

[7] M. Bolyard, P.S. Fair, D.P. Hautman, Occurrence of chlorate in hypochlorite solutions used for drinking water disinfection, Environ. Sci. Technol. 26 (1992) 1663-1665.

[8] B.S. Oh, S.G. Oh, Y.Y. Hwang, H.-W. Yu, J.-W. Kang, I.S. Kim, Formation of hazardous inorganic by-products during electrolysis of seawater as a disinfection process for desalination, Sci. Total Environ. 408 (2010) 5958-5965.

[9] O. Azizi, D. Hubler, G. Schrader, J. Farrell, B.P. Chaplin, Mechanism of perchlorate formation on boron-doped diamond film anodes, Environ. Sci. Technol. 45 (2011) 10582-10590.

[10] G.A. Boorman, Drinking water disinfection byproducts: review and approach to toxicity evaluation, Environ. Health Perspect. 107 (1999) 207.

[11] C.S. Bruning-Fann, J. Kaneene, The effects of nitrate, nitrite and N-nitroso compounds on human health: a review, Vet. Hum. Toxicol. 35 (1993) 521-538.

[12] M.A. Greer, G. Goodman, R.C. Pleus, S.E. Greer, Health effects assessment for environmental perchlorate contamination: the dose response for inhibition of thyroidal radioiodine uptake in humans, Environ. Health Perspect. 110 (2002) 927.

[13] E. McAdam, S. Judd, Biological treatment of ion-exchange brine regenerant for re-use: A review, Sep. Purif. Technol. 62 (2008) 264-272.

[14] J. Liu, J.K. Choe, Z. Sasnow, C.J. Werth, T.J. Strathmann, Application of a Re-Pd bimetallic catalyst for treatment of perchlorate in waste ion-exchange regenerant brine, Water Res. 47 (2013) 91-101.

[15] J.K. Choe, M.H. Mehnert, J.S. Guest, T.J. Strathmann, C.J. Werth, Comparative assessment of the environmental sustainability of existing and emerging perchlorate treatment technologies for drinking water, Environ. Sci. Technol. 47 (2013) 4644-4652.

[16] J.K. Choe, A.M. Bergquist, S. Jeong, J.S. Guest, C.J. Werth, T.J. Strathmann, Performance and life cycle environmental benefits of recycling spent ion exchange brines by catalytic treatment of nitrate, Water Res. 80 (2015) 267-280.

[17] B.P. Chaplin, M. Reinhard, W.F. Schneider, C. Schüth, J.R. Shapley, T.J. Strathmann, C.J. Werth, Critical review of Pd-based catalytic treatment of priority contaminants in water, Environ. Sci. Technol. 46 (2012) 3655-3670.

[18] S. Hörold, K.-D. Vorlop, T. Tacke, M. Sell, Development of catalysts for a selective nitrate and nitrite removal from drinking water, Catal. Today 17 (1993) 21-30. 
[19] D. Shuai, D.C. McCalman, J.K. Choe, J.R. Shapley, W.F. Schneider, C.J. Werth, Structure sensitivity study of waterborne contaminant hydrogenation using shape-and size-controlled Pd nanoparticles, ACS Catal. 3 (2013) 453-463.

[20] Y. Wang, J. Liu, P. Wang, C.J. Werth, T.J. Strathmann, Palladium nanoparticles encapsulated in core-shell silica: A structured hydrogenation catalyst with enhanced activity for reduction of oxyanion water pollutants, ACS Catal. 4 (2014) 3551-3559.

[21] Y. Marco, E. García-Bordejé, C. Franch, A.E. Palomares, T. Yuranova, L. Kiwi-Minsker, Bromate catalytic reduction in continuous mode using metal catalysts supported on monoliths coated with carbon nanofibers, Chem. Eng. J. 230 (2013) 605-611.

[22] D. Shuai, J.K. Choe, J.R. Shapley, C.J. Werth, Enhanced activity and selectivity of carbon nanofiber supported Pd catalysts for nitrite reduction, Environ. Sci. Technol. 46 (2012) 2847-2855.

[23] G. Strukul, R. Gavagnin, F. Pinna, E. Modaferri, S. Perathoner, G. Centi, M. Marella, M. Tomaselli, Use of palladium based catalysts in the hydrogenation of nitrates in drinking water: from powders to membranes, Catal. Today 55 (2000) 139-149.

[24] J. Liu, J.K. Choe, Y. Wang, J.R. Shapley, C.J. Werth, T.J. Strathmann, Bioinspired complexnanoparticle hybrid catalyst system for aqueous perchlorate reduction: rhenium speciation and its influence on catalyst activity. ACS Catal. 5 (2015) 511-522.

[25] U. Prüsse, K.-D. Vorlop, Supported bimetallic palladium catalysts for water-phase nitrate reduction, J. Mol. Catal. A: Chem. 173 (2001) 313-328.

[26] S. Ambonguilat, H. Gallard, A. Garron, F. Epron, J.P. Croué, Evaluation of the catalytic reduction of nitrate for the determination of dissolved organic nitrogen in natural waters, Water Res. 40 (2006) 675682.

[27] B.P. Chaplin, E. Roundy, K.A. Guy, J.R. Shapley, C.J. Werth, Effects of natural water ions and humic acid on catalytic nitrate reduction kinetics using an alumina supported $\mathrm{Pd}-\mathrm{Cu}$ catalyst, Environ. Sci. Technol. 40 (2006) 3075-3081.

[28] W.W. McNab, R. Ruiz, M. Reinhard, In-situ destruction of chlorinated hydrocarbons in groundwater using catalytic reductive dehalogenation in a reactive well: Testing and operational experiences, Environ. Sci. Technol. 34 (2000) 149-153.

[29] M.G. Davie, H. Cheng, G.D. Hopkins, C.A. LeBron, M. Reinhard, Implementing heterogeneous catalytic dechlorination technology for remediating TCE-contaminated groundwater, Environ. Sci.

Technol. 42 (2008) 8908-8915.

[30] C. Schüth, N.-A. Kummer, C. Weidenthaler, H. Schad, Field application of a tailored catalyst for hydrodechlorinating chlorinated hydrocarbon contaminants in groundwater, Appl. Catal., B 52 (2004) 197-203.

[31] S. Nishimura, Handbook of Heterogeneous Catalytic Hydrogenation for Organic Synthesis; Wiley: New York, 2001.

[32] Y.-C. Lin, G.W. Huber, The critical role of heterogeneous catalysis in lignocellulosic biomass conversion, Energy Environ. Sci. 2 (2009) 68-80.

[33] H. Gandhi, G. Graham, R.W. McCabe, Automotive exhaust catalysis, J. Catal. 216 (2003) 433-442.

[34] J. Restivo, O. Soares, J. Órfão, M. Pereira, Metal assessment for the catalytic reduction of bromate in water under hydrogen, Chem. Eng. J. 263 (2015) 119-126.

[35] O.S.G. Soares, J.J. Órfão, M.F.R. Pereira, Activated carbon supported metal catalysts for nitrate and nitrite reduction in water, Catal. Lett. 126 (2008) 253-260. 
[36] O.S. Soares, C.M. Freitas, A.M. Fonseca, J.J. Órfão, M.F. Pereira, I.C. Neves, Bromate reduction in water promoted by metal catalysts prepared over faujasite zeolite, Chem. Eng. J. 291 (2016) 199-205.

[37] C. Freitas, O. Soares, J. Órfão, A. Fonseca, M. Pereira, I. Neves, Highly efficient reduction of bromate to bromide over mono and bimetallic ZSM5 catalysts, Green Chemistry 17 (2015) 4247-4254.

[38] J. Restivo, O. Soares, J. Órfão, M. Pereira, Bimetallic activated carbon supported catalysts for the hydrogen reduction of bromate in water, Catal. Today 249 (2015) 213-219.

[39] J. Liu, X. Chen, Y. Wang, T.J. Strathmann, C.J. Werth, Mechanism and mitigation of the decomposition of an oxorhenium complex-based heterogeneous catalyst for perchlorate reduction in water, Environ. Sci. Technol. 49 (2015) 12932-12940.

[40] R. Baumgartner, K. McNeill, Hydrodefluorination and hydrogenation of fluorobenzene under mild aqueous conditions, Environ. Sci. Technol. 46 (2012) 10199-10205.

[41] R. Baumgartner, G.K. Stieger, K. McNeill, Complete hydrodehalogenation of polyfluorinated and other polyhalogenated benzenes under mild catalytic conditions, Environ. Sci. Technol. 47 (2013) 65456553.

[42] Y.-H. Yu, P.C. Chiu, Kinetics and Pathway of Vinyl Fluoride Reduction over Rhodium, Environ. Sci. Technol. Lett. 1 (2014) 448-452.

[43] Y. Sawama, Y. Yabe, M. Shigetsura, T. Yamada, S. Nagata, Y. Fujiwara, T. Maegawa, Y. Monguchi, H. Sajiki, Platinum on carbon-catalyzed hydrodefluorination of fluoroarenes using isopropyl alcohol-water-sodium carbonate combination, Adv. Synth. Catal. 354 (2012) 777-782.

[44] X.Huo, D. Van Hoomissen; J. Liu, S. Vyas, T. Strathmann. Hydrogenation of aqueous nitrate and nitrite with ruthenium catalysts. (submitted).

[45] D.R. Vardon, M.A. Franden, C.W. Johnson, E.M. Karp, M.T. Guarnieri, J.G. Linger, M.J. Salm, T.J. Strathmann, G.T. Beckham, Adipic acid production from lignin, Energy Environ. Sci. 8 (2015) 617-628.

[46] D.R. Vardon, B.K. Sharma, H. Jaramillo, D. Kim, J.K. Choe, P.N. Ciesielski, T.J. Strathmann, Hydrothermal catalytic processing of saturated and unsaturated fatty acids to hydrocarbons with glycerol for in situ hydrogen production, Green Chem. 16 (2014) 1507-1520.

[47] E.P. Maris, R.J. Davis, Hydrogenolysis of glycerol over carbon-supported Ru and Pt catalysts, J. Catal. 249 (2007) 328-337.

[48] H. Chen, Z. Xu, H. Wan, J. Zheng, D. Yin, S. Zheng, Aqueous bromate reduction by catalytic hydrogenation over $\mathrm{Pd} / \mathrm{Al}_{2} \mathrm{O}_{3}$ catalysts, Appl. Catal., B 96 (2010) 307-313.

[49] W. Sun, Q. Li, S. Gao, J.K. Shang, Highly efficient catalytic reduction of bromate in water over a quasi-monodisperse, superparamagnetic $\mathrm{Pd} / \mathrm{Fe}_{3} \mathrm{O}_{4}$ catalyst, J. Mater. Chem. A 1 (2013) 9215-9224.

[50] K.D. Hurley, J.R. Shapley, Efficient heterogeneous catalytic reduction of perchlorate in water, Environ. Sci. Technol. 41 (2007) 2044-2049.

[51] J. Liu, J.K. Choe, Y. Wang, J.R. Shapley, C.J. Werth, T.J. Strathmann, Bioinspired complexnanoparticle hybrid catalyst system for aqueous perchlorate reduction: Rhenium speciation and its influence on catalyst activity, ACS Catal. 5 (2015) 511-522.

[52] J.K. Choe, J.R. Shapley, T.J. Strathmann, C.J. Werth, Influence of rhenium speciation on the stability and activity of Re/Pd bimetal catalysts used for perchlorate reduction, Environ. Sci. Technol. 44 (2010) 4716-4721.

[53] K.D. Hurley, Y. Zhang, J.R. Shapley, Ligand-enhanced reduction of perchlorate in water with heterogeneous Re-Pd/C catalysts, J. Am. Chem. Soc. 131 (2009) 14172-14173. 
[54] J. Liu, M. Han, D. Wu, X. Chen, J.K. Choe, C.J. Werth, T.J. Strathmann, A new bioinspired perchlorate reduction catalyst with significantly enhanced stability via rational tuning of rhenium coordination chemistry and heterogeneous reaction pathway, Environ. Sci. Technol. 50 (2016) 5874-5881.

[55] C.I. Contescu, C.M. Brown, Y. Liu, V.V. Bhat, N.C. Gallego, Detection of hydrogen spillover in palladium-modified activated carbon fibers during hydrogen adsorption, J. Phys. Chem. C 113 (2009) 5886-5890.

[56] L. Chen, A.C. Cooper, G.P. Pez, H. Cheng, Mechanistic study on hydrogen spillover onto graphitic carbon materials, J. Phys. Chem. C 111 (2007) 18995-19000.

[57] P. Zhang, F. Jiang, H. Chen, Enhanced catalytic hydrogenation of aqueous bromate over Pd/mesoporous carbon nitride, Chem. Eng. J. 234 (2013) 195-202.

[58] H. Shin, S. Jung, S. Bae, W. Lee, H. Kim, Nitrite reduction mechanism on a Pd surface, Environ. Sci. Technol. 48 (2014) 12768-12774.

[59] D.L. Phillips, Palladium-Catalyzed Destruction of Nitro Aromatic-Contaminated Groundwater. M.S. Thesis, Air Force Institute of Technology, March 2003.

[60] T.T. Bovkun, Y. Sasson, J. Blum, Conversion of chlorophenols into cyclohexane by a recyclable PdRh catalyst, J. Mol. Catal. A: Chem. 242 (2005) 68-73.

[61] A. Ghattas, R. Abu-Reziq, D. Avnir, J. Blum, Exhaustive hydrodechlorination of chlorinated aromatic environmental pollutants to alicyclic compounds, Green Chem. 5 (2003) 40-43. 
Table 1. Catalyst information and characterization data.

\begin{tabular}{|c|c|c|c|c|c|c|}
\hline Entry & Metal & $\begin{array}{c}\text { Supplier and } \\
\text { catalog number }\end{array}$ & $\begin{array}{l}\text { Surface area } \\
\left(\left(\mathrm{m}^{2} \mathrm{~g}^{-1}\right)\right.\end{array}$ & $\begin{array}{c}\text { Average } \\
\text { pore size } \\
\text { (nm) }\end{array}$ & $\begin{array}{c}\text { Metal } \\
\text { dispersion }\end{array}$ & $\begin{array}{c}\text { Metal particle } \\
\text { diameter } \\
(\mathrm{nm})\end{array}$ \\
\hline \multicolumn{7}{|c|}{ Activated Carbon Support } \\
\hline 1 & $5 \mathrm{wt} \% \mathrm{Pd}$ & Sigma-Aldrich \#205680 & 958 & 3.1 & $30.3 \%$ & 3.7 \\
\hline 2 & $5 \mathrm{wt} \% \mathrm{Rh}$ & Sigma-Aldrich \#206164 & 870 & 3.6 & $31.3 \%$ & 3.5 \\
\hline 3 & $5 \mathrm{wt} \% \mathrm{Ru}$ & Alfa-Aesar \#44338 & 704 & 3.4 & $11.2 \%$ & 11.8 \\
\hline 4 & $5 \mathrm{wt} \% \mathrm{Pt}$ & Sigma-Aldrich \#205931 & 1370 & 3.4 & $23.9 \%$ & 4.7 \\
\hline 5 & $1 \mathrm{wt} \% \mathrm{Ir}$ & Alfa-Aesar \#38330 & 839 & 3.3 & $31.8 \%$ & 3.7 \\
\hline \multicolumn{7}{|c|}{ Alumina Support } \\
\hline 6 & $5 \mathrm{wt} \% \mathrm{Pd}$ & Sigma-Aldrich \#205710 & 106 & 8.9 & $66.3 \%$ & 1.7 \\
\hline 7 & $5 \mathrm{wt} \% \mathrm{Rh}$ & Sigma-Aldrich \#212857 & 168 & 10.0 & $64.1 \%$ & 1.7 \\
\hline 8 & $5 \mathrm{wt} \% \mathrm{Ru}$ & Sigma-Aldrich \#381152 & 93 & 15.3 & $9.8 \%$ & 13.5 \\
\hline 9 & $5 \mathrm{wt} \% \mathrm{Pt}$ & Sigma-Aldrich \#205974 & 94 & 9.2 & $23.4 \%$ & 4.8 \\
\hline
\end{tabular}

Table 2. Intial turnover frequencies for the reaction of $1 \mathrm{mM}$ oxyanions with $\mathrm{M} / \mathrm{C}$ and $\mathrm{M} / \mathrm{Al}_{2} \mathrm{O}_{3}$.

\begin{tabular}{|c|c|c|c|c|c|c|c|}
\hline \multirow[t]{3}{*}{ Entry } & \multirow[t]{3}{*}{ Catalyst } & \multicolumn{6}{|c|}{$\begin{array}{l}\text { Catalytic oxyanion reduction turnover frequency } \\
\left(\mathrm{TOF}_{0}, \mathrm{~min}^{-1}\right)^{a}\end{array}$} \\
\hline & & \multicolumn{2}{|c|}{$\mathrm{BrO}_{3}{ }^{-}$} & \multicolumn{2}{|c|}{$\mathrm{ClO}_{3}{ }^{-}$} & \multicolumn{2}{|c|}{$\mathrm{NO}_{3}{ }^{-}$} \\
\hline & & $\mathrm{pH} 7.2$ & $\mathrm{pH} 3.0$ & $\mathrm{pH} 7.2$ & $\mathrm{pH} 3.0$ & $\mathrm{pH} 7.2$ & $\mathrm{pH} 3.0$ \\
\hline 1 & $\mathrm{Pd} / \mathrm{C}(10)^{b}$ & $2.7 \pm 0.1^{c}$ & $33.4 \pm 2.7$ & $0.0012 \pm 0.0005$ & $0.070 \pm 0.002$ & $\mathrm{ND}^{d}$ & ND \\
\hline 2 & $\mathrm{Rh} / \mathrm{C}(9)$ & $54.4 \pm 5.5$ & $32.3 \pm 0.6$ & $0.17 \pm 0.01$ & $6.7 \pm 0.5$ & $0.0019 \pm 0.0001$ & $0.046 \pm 0.004$ \\
\hline 3 & $\mathrm{Ru} / \mathrm{C}(8)$ & $2.0 \pm 0.1$ & $1.3 \pm 0.5$ & $6.0 \pm 1.1$ & $0.11 \pm 0.01$ & $0.33 \pm 0.01$ & $0.71 \pm 0.01$ \\
\hline 4 & $\mathrm{Pt} / \mathrm{C}(10)$ & $3.7 \pm 0.1$ & $42.9 \pm 0.4$ & $0.0076 \pm 0.0010$ & $0.090 \pm 0.006$ & ND & ND \\
\hline 5 & $\mathrm{Ir} / \mathrm{C}(9)$ & $15.5 \pm 0.5$ & $47.0 \pm 1.9$ & $0.061 \pm 0.003$ & $1.2 \pm 0.1$ & ND & ND \\
\hline 6 & $\mathrm{Pd} / \mathrm{Al}_{2} \mathrm{O}_{3}$ & $0.83 \pm 0.01$ & & ND & & ND & \\
\hline 7 & $\mathrm{Rh} / \mathrm{Al}_{2} \mathrm{O}_{3}$ & $5.9 \pm 0.6$ & & $0.014 \pm 0.001$ & & $0.0025 \pm 0.0001$ & \\
\hline 8 & $\mathrm{Ru} / \mathrm{Al}_{2} \mathrm{O}_{3}$ & $7.0 \pm 0.4$ & & $1.1 \pm 0.1$ & & $0.30 \pm 0.02$ & \\
\hline 9 & $\mathrm{Pt} / \mathrm{Al}_{2} \mathrm{O}_{3}$ & $6.5 \pm 0.3$ & & $0.0058 \pm 0.0001$ & & ND & \\
\hline
\end{tabular}

${ }^{a}$ Determined for catalyst reactions with $1 \mathrm{mM}$ oxyanions, $22^{\circ} \mathrm{C}$, continuous mixing and sparging with 1 atm $\mathrm{H}_{2} .0 .1 \mathrm{~g} \mathrm{~L}^{-1}$ catalyst suspensions used for reactions with $\mathrm{BrO}_{3}{ }^{-}, 0.5 \mathrm{~g} \mathrm{~L}^{-1}$ used for $\mathrm{ClO}_{3}{ }^{-}$and $\mathrm{NO}_{3}{ }^{-}$.

${ }^{b}$ Number in parenthesis indicate the Periodic Table group number of the hydrogenation metal.

${ }^{c}$ Errors represent $95 \%$ confidence intervals.

${ }^{d}$ Meaningful catalytic activity not detected within the $4 \mathrm{~h}$ of reaction at the $0.5 \mathrm{~g} \mathrm{~L}^{-1}$ catalyst loading. 

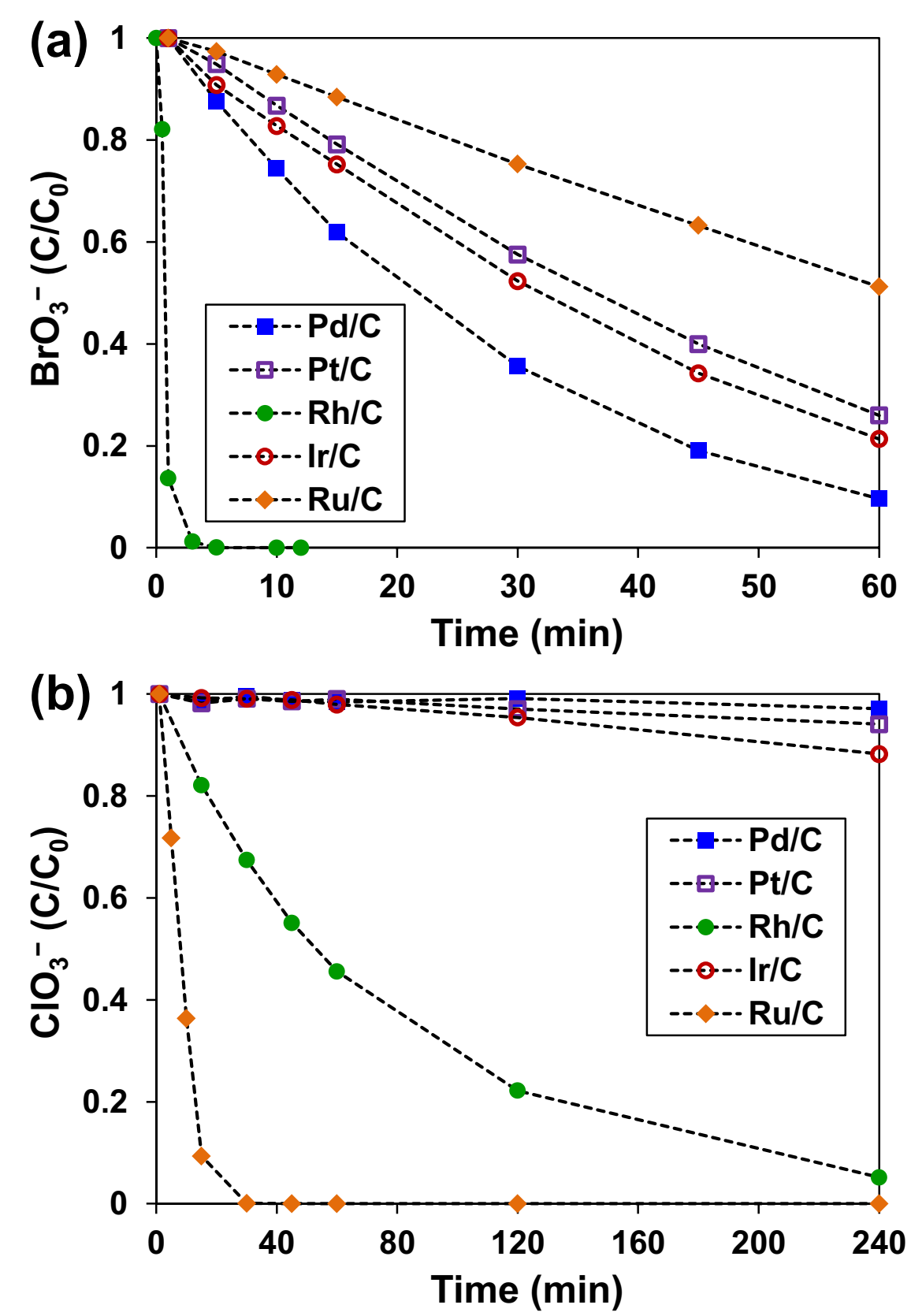

Figure 1. Timecourse profiles with for reduction of (a) $1 \mathrm{mM} \mathrm{BrO}_{3}^{-}$by $0.1 \mathrm{~g} \mathrm{~L}^{-1} \mathrm{M} / \mathrm{C}$ catalysts and (b) $1 \mathrm{mM} \mathrm{ClO}_{3}{ }^{-}$by $0.5 \mathrm{~g} \mathrm{~L}^{-1} \mathrm{M} / \mathrm{C}$ catalysts with 1 atm $\mathrm{H}_{2}$ at $\mathrm{pH} 7.2$ and $22^{\circ} \mathrm{C}$ (nominal $5 \mathrm{wt} \%$ metal for $\mathrm{Pd}, \mathrm{Rh}, \mathrm{Ru}$, and $\mathrm{Pt} ; 1 \mathrm{wt} \%$ metal for $\mathrm{Ir}$ ). 

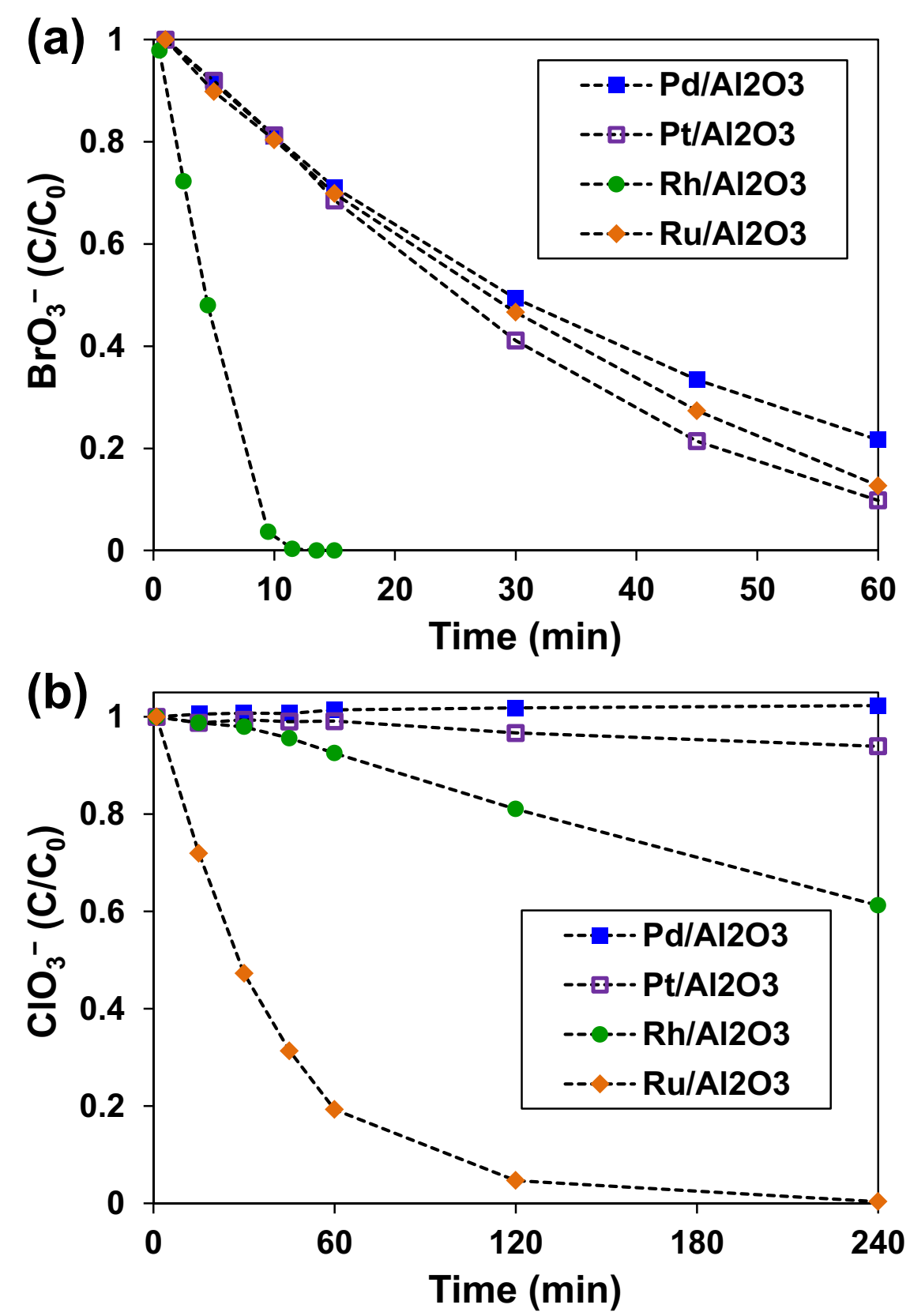

Figure 2. Timecourse profiles with for reduction of (a) $1 \mathrm{mM} \mathrm{BrO}_{3}^{-}$by $0.1 \mathrm{~g} \mathrm{~L}^{-1} \mathrm{M} / \mathrm{Al}_{2} \mathrm{O}_{3}$ catalysts and (b) $1 \mathrm{mM} \mathrm{ClO}_{3}{ }^{-}$by $0.5 \mathrm{~g} \mathrm{~L}^{-1} \mathrm{M} / \mathrm{Al}_{2} \mathrm{O}_{3}$ catalysts with 1 atm $\mathrm{H}_{2}$ at $\mathrm{pH} 7.2$ and $22^{\circ} \mathrm{C}$ (nominal $5 \mathrm{wt} \%$ metal for all catalysts). 


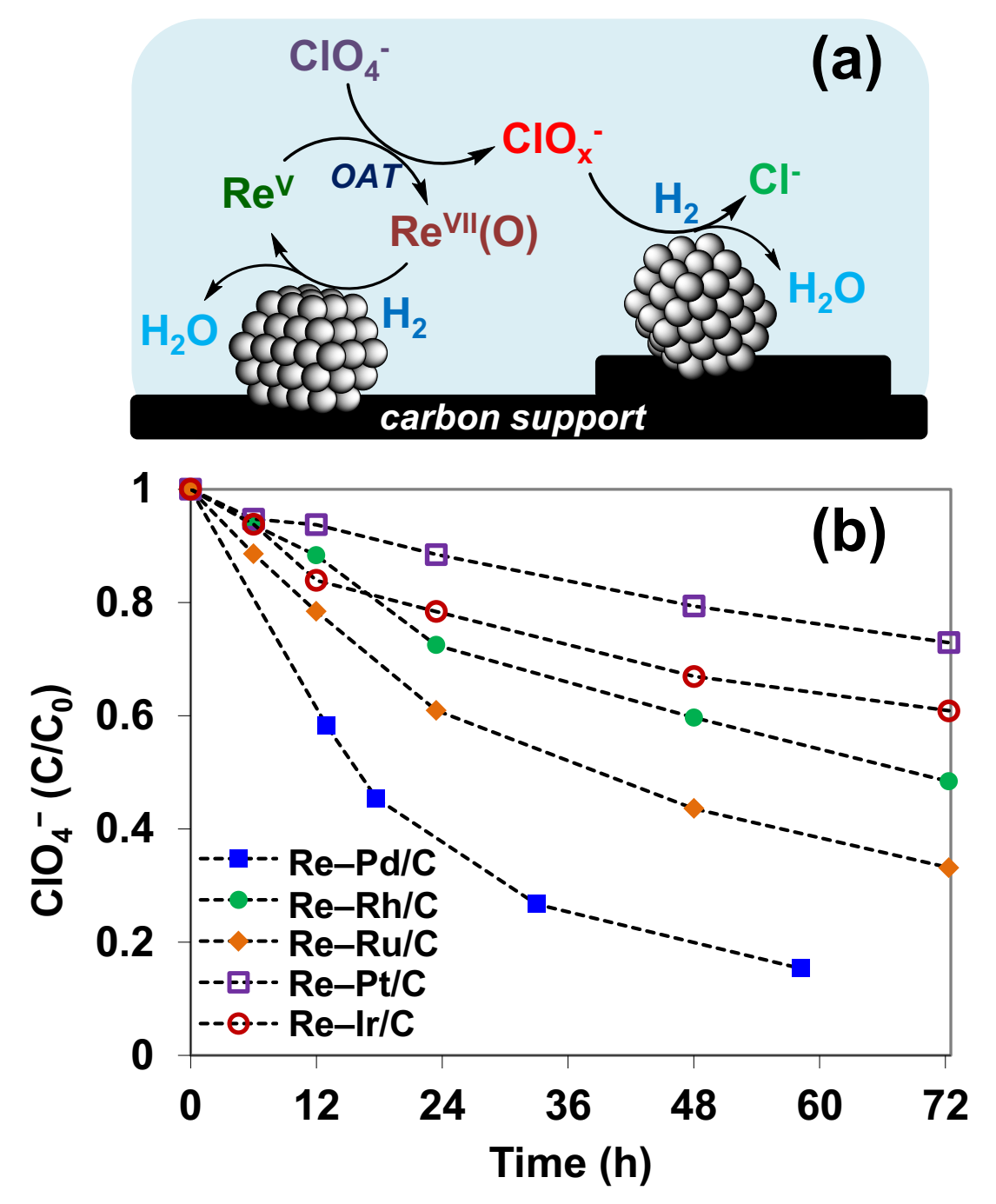

Figure 3. (a) Mechanisms for $\mathrm{Re}-\mathrm{M} / \mathrm{C}$ catalyst reactions with $\mathrm{ClO}_{4}{ }^{-}$and $\mathrm{ClO}_{\mathrm{x}}{ }^{-}$intermediates (x $=3,2$, or 1); adapted from Refs [50, 51]. (b) Reduction of $5 \mathrm{mM} \mathrm{ClO}_{4}{ }^{-}$with $2 \mathrm{~g} \mathrm{~L}^{-1} \mathrm{Re}-\mathrm{M} / \mathrm{C}(5$ wt $\%$ Re, 5 wt $\%$ M) bimetallic catalysts. 


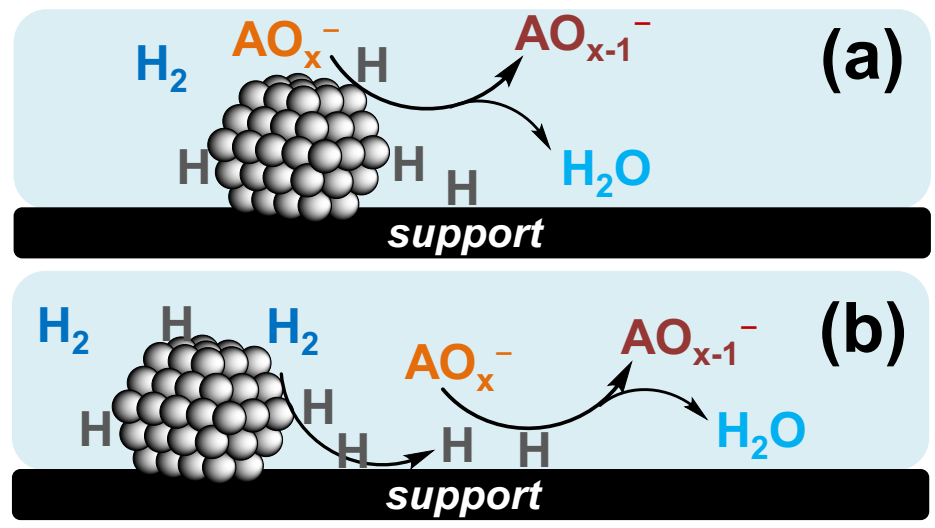

Figure 4. Mechanism illustrations of (a) the reduction of oxyanion substrates $\left(\mathrm{AO}_{\mathrm{x}}{ }^{-}\right)$requiring direct interaction with the hydrogenation metal nanoparticles; (b) the reaction between $\mathrm{AO}_{\mathrm{x}}{ }^{-}$and spilled over atomic hydrogen at the catalyst support surface away from the hydrogenation metal nanoparticles. 

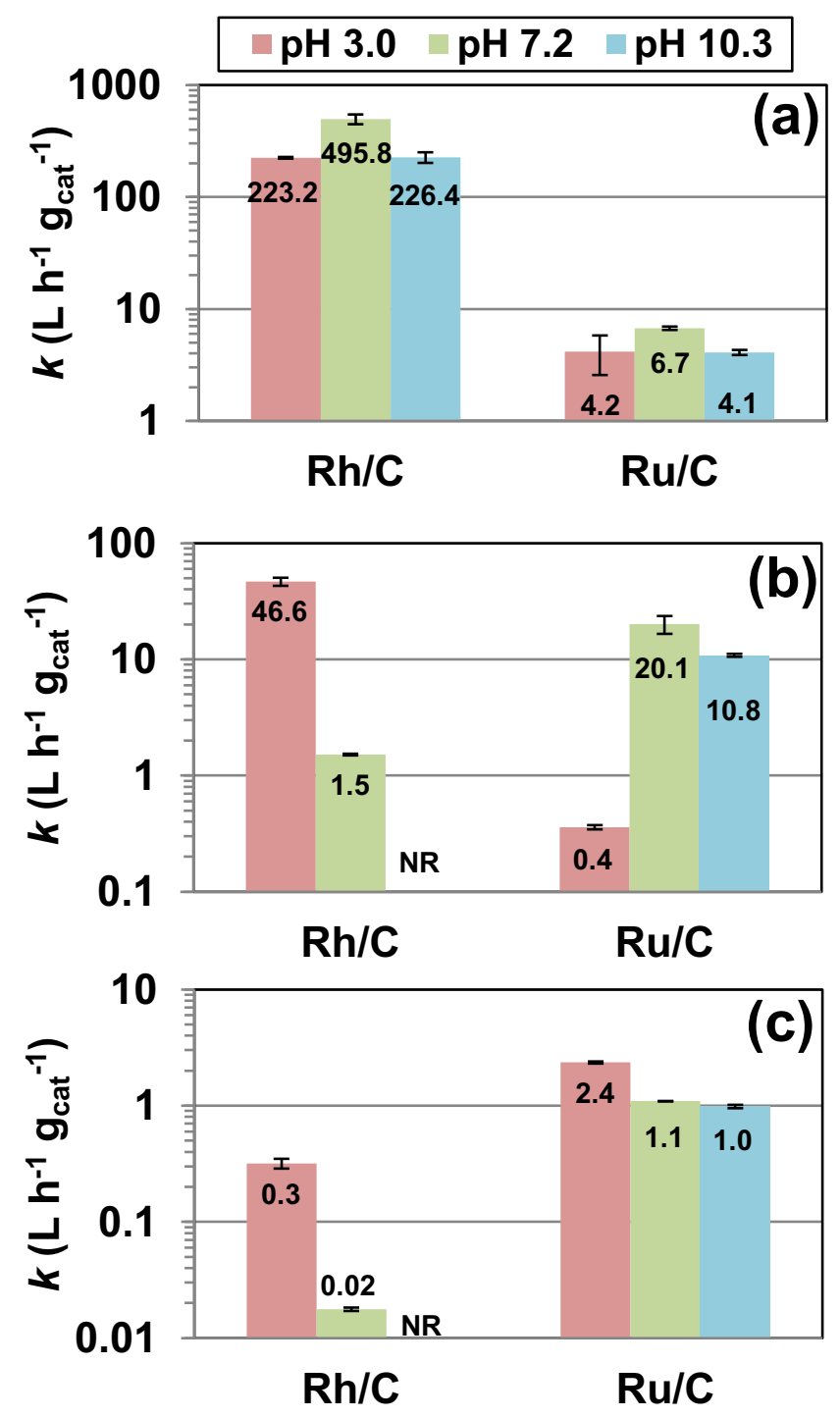

Figure 5. Catalyst loading normalized rate constants at different $\mathrm{pH}$ for the reduction of $1 \mathrm{mM}$ (a) $\mathrm{BrO}_{3}{ }^{-}$, (b) $\mathrm{ClO}_{3}{ }^{-}$and (c) $\mathrm{NO}_{3}{ }^{-}$with $\mathrm{Rh} / \mathrm{C}$ and $\mathrm{Ru} / \mathrm{C}$ catalysts. Error bars represent replicateaveraged $95 \%$ confidence intervals. "NR" indicates no reaction observed within the reaction period monitored. 


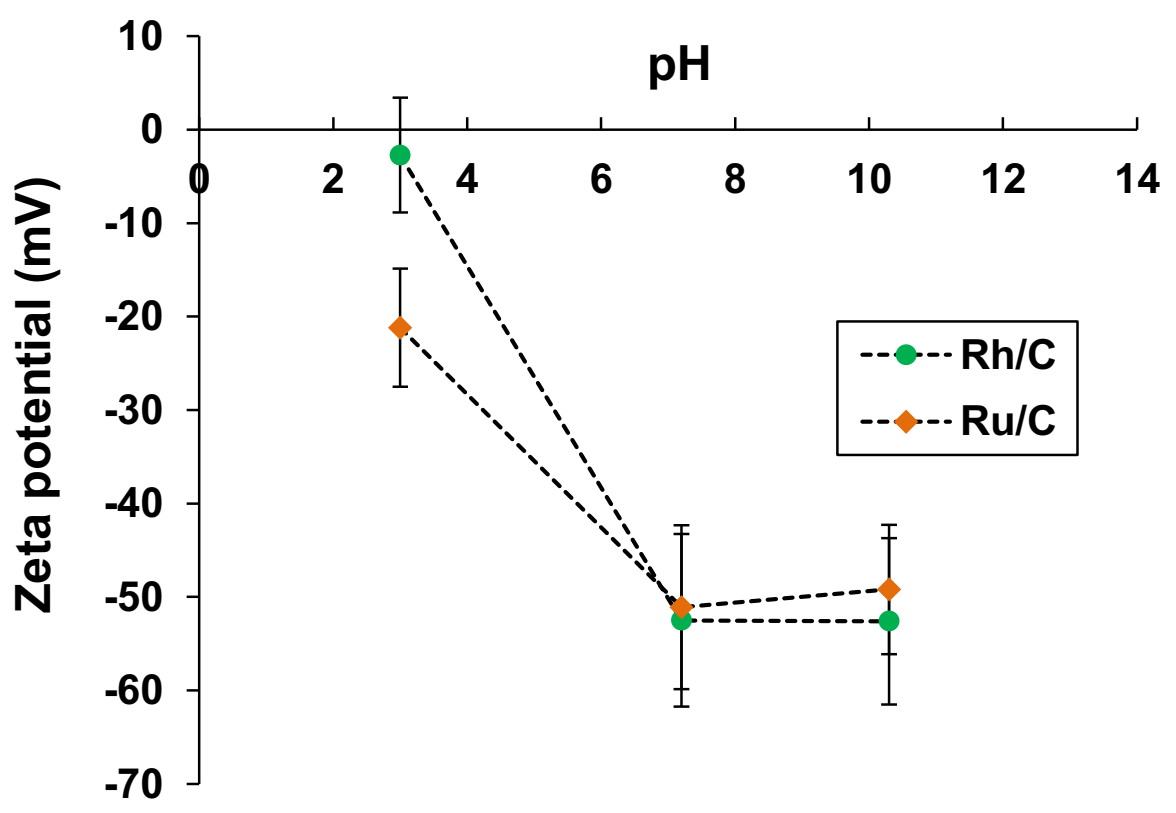

Figure 6. Influence of $\mathrm{pH}$ on the zeta potential of $0.5 \mathrm{~g} \mathrm{~L}^{-1} \mathrm{Rh} / \mathrm{C}$ and $\mathrm{Ru} / \mathrm{C}$ catalysts in $\mathrm{H}_{2^{-}}$ saturated aqueous suspension at $22{ }^{\circ} \mathrm{C}$. 